Informasi - ISSN (p) 0126-o650; ISSN (e) 2502-3837

Vol. 5o, No. 2 (2020), pp. 153-164 doi: http://doi.org/10.21831/informasi.v50i2.28463

\title{
Millennial generation and family literacy within the dissemination of hoax in Whatsapp group
}

\author{
Ririn Puspita Tutiasri \\ Prodi Ilmu Komunikasi, FISIP UPN Veteran Jawa Timur \\ ririn_puspita.ilkom@upnjatim.ac.id \\ Ade Kusuma \\ Prodi Ilmu Komunikasi, FISIP UPN Veteran Jawa Timur \\ adekusuma185@gmail.com
}

Article History: Received 2019-11-29, Revised 2020-11-23, Accepted 2020-11-30

\begin{abstract}
The millennial generation emerges in the era of advanced technology. The characters of the generation tend to have advanced knowledge of both technology and information. This convenience, spreading information easily, causes difficulty identifying whether or not the news is factual. Media literacy is necessary for millennials considering this generation is familiar with modern technology. Data are collected through observations and in-depth interviews. The analysis results that spreading Hoax via group chat is capable of anyone, including close and trusted family members. To prevent the act of disseminating Hoax in family and sibling, thus, a family member has an important role in reminding each other of the relevance of media literacy. This study concludes that knowledge and mastery of technology and the management of information from millennials are essential. Therefore the spreading Hoax is diminished. Literacy from generation to response disseminating Hoax in WhatsApp group provides knowledge to group members, especially parent, to be not gullible and easily provoked to single information. The opportunity of disseminating Hoax through a family group in WhatsApp is higher because of the mutual trust among family members and shared the information without clarifying it.
\end{abstract}

Keywords: Family Literacy, Hoax Information, Whatsapp Group 


\section{INTRODUCTION}

The rapid flow of technology has driven the fast flow of information. When information is uploaded through technology, the information has widespread throughout the world and difficult to retrieve within seconds.

The advance of technology also causes a social shift in society (Anderson \& Sulistyani, 2019). For instance, a long time ago, to know and to get information is by reading, but now is by browsing. For instance, to know how our neighbor is doing by greeting each other or visiting them, but today by checking their status in social media is enough. Social media is a product of technology to simplify space and time to search for information, interact, and share information with others.

Social media's positive impact is to make its users closer as if they are near each other by knowing other users' information when they share or upload a status or information on social media. Social media appeared in 2002 by launching Friendster's application and followed by other social media such as Linkedin, MySpace, Flickr, Facebook, and Twitter to connect users to exchange information. Through social media application, people can share information and make a friend, even, making someone famous.

In 2009 WhatsApp application appeared as a chat application when its users share information personally, not openly like on Instagram, Facebook, Linkedin, MySpace, Twitter, Path, Friendster or other apps that the users can actively involve to share, participate, comment, and communicate interactively. WhatsApp is a chatting application or instant messenger that focuses on sending a message in text, picture, or voice in person or a group to create an interaction between the users. WhatsApp replaces SMS and phone calls at a lower price because phone calls and SMS use credit, whereas this application only uses an internet quota. Smartphone users commonly use the application because the amount of WhatsApp users in Indonesia had reached $83 \%$ from 150 million, and most of the active internet users were social media users (Haryanto, 2019).

The family group in WhatsApp is useful for a family member who lives in a different town. The members always expect to be closer. Family is a bloodline relationship; from a family, a person grows up and developed with values that have been taught by the family. Besides, a family is a primary group because interaction among the members is exclusive. Family relationship is not only through bloodline but also through marriage or adoption. In the family WhatsApp group, the shared information is spread easily to group members.

The content itself is about a warning, problem solution, happy news, and other news that is intended for the good of family members. The shared news includes family conditions, politics, health, economics, religions, and socials, which sometimes trigger feud among the members. The feuds usually start with an unclear and false source of information that contains offensive meaning to other family members. Information causes disagreement because the truth of the information is doubtful or Hoax in nature - especially parents in the group who have not adequately filter out accurate information or Hoax.

Hoax is a manipulation of fact which turns into false information for specific purposes. Hoax divided into six: false idea, offense principle, media manipulation, balancing, objectivity, and against moral neutrality (Cohen-Almagor, 2013) It makes the need for media literacy capabilities, the ability to analyze. There are four capabilities in media literacy, which are analysis, compare or contrast, evaluation, and abstraction (Potter, 2010)

Literacy defines as an openness towards information from media or information literacy, critical, and sensitive to the surrounding environment. Literacy aims to bring benefits to the community and to give knowledge of how to sort and select a message. Media literacy audiences have few characteristics. Some people are aware of the dangerous effect and degradation of media, 
like a short-tempered person who does not relate to media; others characteristically have an ability to enjoy, understand, and appreciate the content of media (Fitryarini, 2016). It includes millennial roles in the WhatsApp group family. Because consuming a media needs knowledge (Baran \& Davis, 2010), the ability and eagerness to understand and comprehend the meaning of a message or information received is important. Media has power in delivering a message; thus, the receiver has to own knowledge and appreciation of media message power. The receiver also needs to differentiate a reaction and emotional reason while responding to the message's content of information appropriately. They are establishing a high hope to media by constructing a strategy to analyze and discuss media messages, understanding the content of media as knowledge of conversion genre along with an ability to instigate when the content is mixed-up. Critical thinking to media content is significant even though it has a credible source. The last is the importance of internal language and a comprehensive skill on understanding media's complicated effects.

Meanwhile, media literacy is a literate media movementas individual control to send and accept a message (Baran \& Davis, 2010). Media literacy is a skill in media sequence in every situation, time, and media. Based on the definition of media literacy, media users need to act when accepting information. It is necessary to know the truth of the information and evaluate the utilization of media. Therefore, the literacy movement on social media is essential because the technology to filter the truth about information has not been made yet. The ability of media literacy among the millennial generation towards spreading hoax in the WhatsApp group is the background of this research.

\section{LITERATURE REVIEW}

\section{Media Literacy}

The development of time and technology causes the need for media monitoring or literacy to its users to filter information obtained from the media. Media literacy teaches the public to be critical when receiving information through the media, not directly receiving the message.

Critical media requires skills and abilities in sorting and selecting messages received in the media. In reaching critical media literacy and awareness, we need seven skills (Potter, 2018) which are: first, analysis ability to reduce the received message into meaningful elements: second, evaluation over the meaning of the elements: third, grouping, it is categorizing whether the elements are similar or different to each other: fourth, induction is concluding the previous grouping by generalizing the elements' pattern: the fifth is deduction, using the general principle to explain the specific matter: sixth is synthesis, gathering the elements into a new structure: seventh is an abstraction, creating a brief, clear, and accurate description to develop the essence of assumption from a message which is briefer than the original message.

Media literacy is essential because of the strong influence of the media on the public. Through media literacy, the public can understand how to influence and use media properly.

\section{Family}

A family is a primary group in human life, a place for a person grows up, develop, and learns. The family also a place of comfort and care for its member. Through a family, values, norms, and principal of life are embedded because family is a prior group to figure the meaning of life of a person. The family has several functions for its members, which is reproduction and emotional socialization, and economic support function. This is a series of life that exists in a primary group, when appropriate growth and development, while its members are still dependent on each other (Tutiasri et al., 2019)

Within the WhatsApp Group, it is easy to share messages containing hoaxes due to kinship, to which the Whatsapp group is used as a medium for interacting and sharing news with family members. Communication 
in a family is a process of expressing a message among its members like from the father, mother, grandparents, children, husband, wife, in-laws to the receiver, and vice versa. The messages though can be information, advice, direction, or favor.

Berns wrote five basic functions of families: (Berns, 1997). First is reproduction because a family has to maintain the population in a community due to the continuity of the human population: the second function is socialization or education; the family is the media of transmitting moral value, belief, manner, knowledge, skill, and technique from the previous generation to the next generation. Family is a place to connect a value from one generation to another. The third is ascribing social role; family gives identity to its members specifically, for example, race, ethnicity, religion, social economy, and gender role. The fourth is economic supports; family is a shelter and life for its members, such as a house, food, and life.

The last is emotional supports; family gives an experience in communication and social interaction for children. Family interaction creates nurture, secure, and vital experience for children.

\section{Family WhatsApp Group}

Technological advances have created many innovations in technology, one of which is in the communication sector. This improvement generates a more effective communication process through emerging gadgets. Gadget on android has changed the process of communication through its sophisticated features such as WhatsApp. WhatsAppisaninstantmessengerapplication. Its users are capable of communicating by sending messages, pictures, audio, visual audio, and making a call both on voice and video call (Tutiasri et al., 2019). This application connects person-on-person and connects a person in a group that is currently known as WhatsApp Group (Rianto, 2016) message and information exchange in WhatsApp Group is considered interesting because dialogues or conversations are always ongoing, although particular people dominate those conversations. Participants' characteristic is categorized into two: active and passive members or silent readers, who only observe the conversation in the group.

Many families utilize the WhatsApp group as a medium of communication within their main or big families. The purpose of this group becomes a medium of communication because it has a lot of benefits. The WhatsApp group's benefits are strengthening the relationship among the members, increasing self-faith of its members, a place forgiving and receiving attention, reminding each member about something, and exchanging messages or information. (Prasanti \& Indriani, 2016)

\section{Millennial Generation}

The millennial generation was born between early 1980 and 200o. This generation is also named Gen-Y, Net Generation, Generation WE, Boomerang Generation, Peter Pan Generation, and the others (Yuswohady, 2016). They are called the millennial generation because they live in the millennial generation's alteration, with the advent of the technological era. Hoax information is the negative impact of technology. A lot of information or messages are unverified (Berger \& Milkman, 2012).

Many information or news on social media are able to raise positive and negative emotions to the receiver. The viral news is distributed without any verification from journalism ethics and media law. It frequently happens on social media users who are not journalists; there is no control over journalism, which affects the data and information on social media. (Gumgum et al., 2017) False or Hoax news that is spread on online media has complicated the receiver or audience to decide which one of this information is valid or not. False information triggers conflicts among the audiences to claim the validity of their information. 


\section{Theory of Cognitive Development}

Knowledge construction is very carefully related to how social interactions are carried out with the surrounding environment. Adolescence is the stage of development before becoming an adult. During this stage, teenagers have a lot of capacity to gain and apply their knowledge because the brain has developed maturely (Sary, 2017). The adolescent stage is also reorganizing the brain's frontal lobe, which plays a big role in coordinating complex decision-making and creating a strategic plan (Sarlito, 2012). During this stage, mental development has built a cognitive skill to process and filtrate information as a way of thinking process (Jahja, 2011).

Cognitive development is the development of teenagers' mental abilities in the form of learning, memorizing, thinking, reasoning, and using a language. The psychological development during the adolescence stage consists of two developments: mental and cognitive developments. Developmentrelatedtomental is marked by sensitiveness, aggressiveness from external stimulation, tendency to form peer group, and less obedience to parents. Second, during cognitive development, the adolescent develops to think abstractly, such as actively giving critics and a tendency to try anything new (Widyastuti et al., 2009)

\section{METHODS}

This research is a qualitative descriptive study. In general, the research method is defined as a scientific way to obtain data with specific goals and aims. (Sugiyono, 2013). The research method applied in this research, "Millennials and Family Literacy in the distribution of Hoax on WhatsApp Group", was using the qualitative research method. This type of research used by researchers is descriptive research. This research aims to explore in detail about Millenials generation literacy knowledge in educating the existence of hoaxes on social media, such as the WhatsApp family group. in social research, a qualitative descriptive research format is designed to describe, summarize various conditions, situations, or social reality phenomena that exist in the community that is the object of research (Bungin, 2011)

This article also tried to draw it to the surfaceasa feature, characters, characteristics, models, signs, or images, or certain conditions, situations, and phenomena through this method. (Sukmadinata, 2009) In qualitative research is used to describe and analyze phenomena, events, social activities, attitudes, beliefs, perceptions, and people individually or in groups. In the study, researchers conducted interviews with old of 8 informants and ten informants from the millennial generation.

\section{RESULTS AND DISCUSSION}

\section{Media Social as a Communication Media in the Family}

Technological developments have made life more comfortable; you can do what you want by accessing an existing smartphone application. Social media's existence also brings changes to the flow of information, which in face to face changes through a media application. Social media utilization dimensions are divided into the dimensions of information, entertainment, communication, and transactions (Buente \& Robbin, 2008)

Social media can provide dimensions of information, entertainment, communication with transactions that will be well chosen and used (Fadillah \& Jandevi, 2020). Of the four dimensions, the dimensions of communication, information, and entertainment become interesting things for smartphone users to choose the application for their necessity. Most people are still careful to choose the application for their transactions. Different from the other three dimensions, communication, information, and entertainment are necessary for smartphone users because, at this time, they are entering the era of social media.

Technological sophistication makes communication no longer a tertiary or complementary need because every day, we 
are communicating. There are free data and Wi-Fi packages that have made them more efficient than using credit because the pulse package shares costs when making calls and sending messages. The development of the age also makes information quickly spread, and both information is public or personal.

Entertainment is essential considering that today people carry smartphones everywhere. It also changes the way the members interact with one another, whether due to family members, friendship or professional acquaintances. With social media, interaction can be done at any time and by all group members. One of the social media that facilitates interaction to interact through social media is WhatsApp Group. This application is used to share information and to make members closer.

Each group has different interaction levels; the more intimate it goes, the group will discuss personal matters. Unlike the secondary group, conversations rarely involve personal issues because things discussed are related to the same interests. A family is a primary group that the members have a mutual relationship with one another. Among the members are close because they are accustomed to communicating since they were in the family, both born in the family, raised and included in the family membership. It makes the relationship between members are based on feelings and personal relationships.

The characteristics of the primary group: the primary group is deep and broad; thus, exchange information can reach the personality of their members, it is personal, the relationship aspect is more emphasized than the context, it is expressive, the conversation is informal (Cooley, 1992)

WhatsApp group is a medium to interact between family members and to become more intimate and more familiar with each other. The family members can send messages at any time, and other members read the message directly. This makes the WhatsApp family group easily exposed to hoax information because it suppresses the information's relationship aspect rather than the content shared.

Moreover, WhatsApp is a large family group consists of the older generation, the millennial generation, and generation $\mathrm{Z}$, which have different characters. Even so, the purpose of the conversation is to make family relationships more intimate. Moreover, the way the delivery is informal makes the conversation more relaxed and readily accepted. Interaction in the family can lead to dependency between family members. When the family is interacting, a family is a place for the emotions of its members. Emotional disclosure such as sadness, disappointment, fear, happiness, sympathy, and other emotions is easily expressed through family WhatsApp groups. This group also has a big role as a support and motivation medium to its members when facing hardship. Support and motivation are significant as a means of affection and concern considering the family is the first place a person knows interaction. Family members experience changes and affect the system in the family (Wardyaningrum, 2013).

The process of exchanging information develops the family as a place for channeling emotions. Besides, family members interact with each other in high frequency and repeatedly lead to be interdependence between family members. It is making conversations in family groups to build the emotions of family members to know and understand each other. A sense of emotion makes family members have a sense of "tepo seliro" when an event occurs.

This equation makes it easy for family members to remind one another or do literacy when hoax information exists in the family group. Data collection in this study uses an in-depth interview, which is a form of communication between two people, involving someone who obtains information from others by asking questions and having a specific purpose. (Mulyana, 2008)

\section{Old generation's Perspective to Hoax Information}

Changes in the way of delivering information influence us on how to 
understand the information. An old generation used to get information from reading, listen, and see from a source, the accuracy of the information can still be accounted for. Because only a few people who had access to make information, and communication is still going on to ensure the truth of information. This makes it easier for the old generation to believe when there is information coming into them. The development of time and technology makes anyone can make a message, even edit a message quickly.

This is still rarely understood, making the old generation not check the truth of the message he received, even directly sharing it. Especially now, the existence of a smartphone has made information quickly conveyed. Parents tend to disregard the source of information received, whether the information is valid or not. Leaving the information received unchecked is caused by several things: parents do not know how to check the information because they are overwhelmed by technology's advance. Another reason is the receiver has excessive trust to the sender due to the senders' closeness to the receiver

One of the easy Social media applications to use for the old generation is WhatsApp because it is easy to learn. WhatsApp feature is sending messages and making calls that are the same as using the old generation's telephone. WhatsApp Group is a feature to communicate between the oldies and other WhatsApp users, whether they are family or friends. The oldies feel proud when they can follow the development of technology. Their excitement is seen when they join a group. They often send information. The oldies' tendency to lead a discussion causes the information delivery lead to be a reference in the family group.

Hanafi writes an opinion leader is someone who has a relatively significant influence on the opinions or views of other people in a group they have. According to informants from the old's generation, the WhatsApp family group is a place to share all information known by their family members. (Adi \& Setyowati, 2010)

The research conducted on the old generations results that they are not accustomed to filtering the obtained information. Thus hoax information quickly enters itself and is then disseminated. Even some of the informants from the old generation answered that they did not know how to differentiate whether it is hoax news or not.

"masalahnya yang kita teruskan tidak tahu itu hoax apa bukan"

"The problem is we do not know whether it is a hoax or not"

Even when other group members have told it, they still look for the information and sharing misinformation.

"ya, itu saya tidak tahu apakah itu hoax apa bukan, kalau direspon baik ya saya bilang, saya juga hanya meneruskan"

"yes, I didn't even know if it was a hoax or not, if it got a good response, I would say that I just forwarded the information"

Old generations are more susceptible to hoax information than making media literacy necessary to find the truth of information. Some informants of the old generation have sent hoax information when the information is around and easily accessible. An older generation of informants shared information on the WhatsApp group about a fire incident in the market where his wife was working. Supposedly, before sharing, the informant can contact his wife first or contacted security to check the truth first. There are even informants who work in the health sector but also share hoax information about health.

The flow of information in the smartphone of the oldies is high-speed because they follow many groups, ranging from family, office friends, alumni (usually starting from elementary, junior high, high school, college), social institutions, religious institutions, and groups- other groups that exist in real life.

The millennial generation has a better closeness with its peers than the elderly 
generation because their closeness is based on the stored phone number contacts on their phone. Matter of fact, we save the numbers of people we knew. the existence of technological sophistication, one of which is the WhatsApp group, makes the users reunite with friends from their past. Meanwhile, the millennial generation also saves the number of their new acquaintance

Hoax information widely shared by old generations was a video about food products when it burned, the fire from the burning process immediately enlarged. Videos related to health and safety. They share this information with family groups because there is a sense of security that needs to be done to protect family members safely. Whether they are new or old videos, the videos from within a country and abroad are easily shared without checking the truth. The elderly generation gains the videos from the groups they followed and thinks what is shared in the group is true or accurate. Besides their motives for sharing information in family groups so that they are not quiet, they want to live in the family group. Sharing information in the form of messages or videos is purposely to encourage interaction among its members.

Through the WhatsApp Group chat room, the members can acknowledge each other conditions and news. WhatsApp Group plays the role of creating a good bond among the members. Old generation admits that they put more trust in family group members when reminded about hoax information. In addition to the authenticity of the sources, the old generation saw who confirmed the message. By looking at the educational background and the work that confirms the message is credible or not.

To the elderly generation, hoax information is regarded as new because they have not found false information as easy as today. Technological advance has made a piece of information seems vague. There is no difference between false or true information. The spreading Hoax occurs in two forms which are written and image hoax. A message in an orderly structure along with the headlines has convinced a reader to allow this message to be true. Furthermore, an image and source are presented in the message can strengthen the content.

The series of headlines, written content, images, and source that included in a message has complicated the elderly generation to distinguish between true and false information. This situation is the reason why they are so gullible to share the information. While we ask them about the source of information, they claim it is on the image.

The image is proof of a fact, according to the elderly generation. Because there is no existence of technology to edit, add, or cut the content of an image in the earlier generation. Truth-seeking literacy towards specific information or message has been applied by a few millennial members, for example:

"silahkan dicari digoogle tentang berita tersebut, atau ini buktinya informasi tersebut tidak benar, sambil saya bagikan berita yang benar"

"please check on google about this news, or it is the proof that the information is false, hereby I share the true news".

Countless middle age and older people dismiss truth-seeking of information before sharing it. According to them, it is necessary to share the messages they received on a WhatApp group as an act of concern. Then if the information is a hoax, the members still accept it. Many hoaxes widespread today and the millennial's truth-seeking literacy to correct the elderly generation have convinced them that the millennial are capable of distinguishing between true and false information. When he got a message and doubted it, one of our informants said he would ask the group, especially the millennial members, before confirming the sender's message.

“aku gak tahu pesan itu hoax atau tidak, makanya aku tanya digrup, karena biasanya dikomentari kalau aku share pesan dan hoax" 
"I did not know whether the message is a hoax or not. Thus I asked on the group because usually, the members would throw a comment if the information was false"

Reliability to the millennial generation has emerged when the millennial members present a fact to deny hoax information on the WhatsApp group. The elderly generation has begun to accept millennial's information literacy. It shifts message transmission and management. Generally, a message is accurate when it is delivered by parents to children yet today is the contrary. Besides, parents occasionally filtered a message on whether or not it is appropriate for their children. Advanced in the technology of communication has changed this information exchange where everybody has the right to show a truth despite their younger age.

\section{How to Literacy Millenials Generation of Hoax information}

Millennials are the generation that grows with the times and technology, making this generation more alert to changes, including changes in information flow. Social media easily influences users' perceptions when information comes into their smartphones. Forums were easily created through social media, allowing members to communicate and comment so that they were able to build assumptions, emotions, and trust through the information shared. (Hermawan, 2009)

WhatsApp group is a forum used to build trust between family members, including building trust when correcting information. Closeness among family members can be built through WhatsApp group by sending fast information Without direct physical meeting. Sharing daily activities allows the members to feel closer despite in different places. The members share this kind of information on WhatsApp group to show their affection and concern.

From the results of research with ten informants of the millennial generation, they are more passive when sharing information in the family WhatsApp group. Because they, firstly, examine whether the information to be shared is useful or not. According to two informants, they said that they have never shared information that was useless because it would result in the vigilance and intimidation of group members. I was so careful to send information. Once there were informants who felt guilty because they had sent the information and the information had not been released officially, such as:

"Dulu aku pernah dikira nybar hoax, tapi ternyata engga, maksudnya bener beritanya (informasi CPNS, aku dapat info dari grup antar angkatan di organisasi, lalu aku share di grup. Karena tidak ada dilaman, belum di update dikira hoax, tapi itu bener karena pas aku cross check itu dapatnya dari dosen)”

"Last time, I was accused of spreading a hoax, but it wasn't, the news is true (CPNS information from the organization then I shared it to other groups. The shared information does not on the website because it has not updated yet, then other members accused that I shared hoax information. Even though I have cross-checked it was from the lecturer)"

The rise of hoax information creates a trust or raises caution when sending information. Hoax is a fake and misleading message, so that it can frighten those who receive it, be identified, and be classified (Kholis, 2017). Hoax Information is hazardous and unsettling if the truth is not immediately clarified. (Ali, 2017). One of informants gave a similar example,

"Yang sederhana misalnya, di pasar X lagi ribut2 ada jambret, terus jambretnya dipukulin sampai babak belur. Dikirim lah fotonya. Setelah klarifikasi ternyata kejadian sudah beberapa tahun yg lalu, dan beda lokasi”

"The simple thing is, for example, in market $X$ there is pickpocket, and the accused one is beaten to a pulp. The photo was sent. After clarification, it turned out that the incident had been several years ago, and in different locations."

Clarification of hoax information is very important so that the recipient of the 
message does not feel: Alert, scared, agitated, and provoked. To reduce the spread of hoax information can be done in several ways as disclosed by the informants, the first by sharing the original facts of the hoax information, can be a link from the original source of information or the original picture of the information.

Many information that does this when there is hoax information included in the family group. Seeing how big the family group is, or who is a member of the group, some group members choose to send facts from the information in private (personal connection). Personal chat is one of the ways to respect other members when they need to scold or advise others.

Moreover, sending a clear message to older people on personal chat is part of politeness. They are considering that informants revealed differences of opinion between family members at the time of the presidentialelection, which caused problems. Another way is to meet with people who greet the hoax news, usually because there is a closeness of its own and want to convey it in the right way. For example, children to their parents, because they still have the nature of uploading really (polite) so feel uncomfortable when advising their parents, in the family group. By meeting the parent directly, the millennial generation indicates their capability of manners because the tone of voice cannot be shown in media.

From the study results, informants from the millennial generation did several ways in literacy against hoaxes in WhatsApp family group by spread the original information, confirm the truth of information through personal connection, and meet in person. Literacy about hoax information is necessary to be done because one mistake in certain information can lead to an adverse effect on the receiver of the information. Through literacy of hoax information initiated in family, the group is an education facility for family members to check any information.

\section{CONCLUSION}

Millennial easily recognize hoax information because media is part of their habitual life. Whereas in the elderly generation, understanding media literacy is a process of learning from their environment, in this case, is through family WhatsApp group. The group is believed as media to support each member and avoid misleading them because of the affection among the members. As the outcome, mutual trust is constructed among them as well as the truth of information shared on the group. This research reveals that Family WhatsApp Groups have the capability to filter and educate the members about the information received, whether it is accurate or hoaxes.

\section{ACKNOWLEDGMENT}

We would like to appreciate the Communication Science Department, UPN "Veteran" Jawa Timur. And also the committee of COMTC UIN Sunan Kalijaga and JAPELIDI.

\section{REFERENCES}

Adi, R. K., \& Setyowati, R. (2010). Proses difusi teknologi konservasi lahan kering melalui pemuka pendapat (opinion leaders) di Kabupaten Bantul. AGRITEXTS: Journal of Agricultural Extension, 28(2), 117-130. https://doi. org/10.20961/agritexts.v28i2.43666

Ali, M. (2017). Antara komunikasi, budaya dan hoax. In A. Wahyudin \& $\mathrm{M}$. Sunuantari (Eds.), Melawan hoax di media social dan media massa (pp. 89-107). Trust Media Publishing dan ASKOPIS Press. http://e-repository. perpus.iainsalatiga.ac.id/2332/1/ naskah buku melawan hoax.pdf

Anderson, S., \& Sulistyani, H. D. (2019). Detecting and combating fake news on web 2.0 technology in the 2019 political season; Indonesia. Journal of Social Studies (JSS), 15(1). 103-116. doi: 10.21831/jss.v15i2.25233.

Baran, S. J., \& Davis, D. K. (2010). Teori komunikasi massa: Dasar, pergolakan, dan masa depan. Salemba Humanika. 
Berger, J., \& Milkman, K. L. (2012). What makes online content viral? Journal of Marketing Research, 49(2), 192-205. DOI: 10.2139/ssrn.1528077

Berns, R. S. (1997). A generic approach to color modeling. Color Research \& Application: Endorsed by Inter-Society Color Council, The Colour Group (Great Britain), Canadian Society for Color, Color Science Association of Japan, Dutch Society for the Study of Color, The Swedish Colour Centre Foundation, Colour Soc, 22(5), 318-325. https://doi.org/10.1002/ (SICI)1520-6378(199710)22:5<318::AID$\mathrm{COL}_{5}>3.0 . \mathrm{CO} ; 2-\% 23$.

Buente, W., \& Robbin, A. (2008). Trends in internet information behavior, 2000-2004. Journal of the American Society for Information Science and Technology, 59(11), 1743-176o. https:// doi.org/10.1002/asi.20883.

Bungin, B. (2011). Metode penelitian kuantitatif edisi kedua. Jakarta: Kencana.

Cohen-Almagor, R. (2013). Freedom of expression V. Social responsibility: Holocaust denial in Canada. Journal of Mass Media Ethics, 28(1), 42-56. https://doi.org/10.1080/o8900523.2012. 746119 .

Cooley, C. H. (1992). Human nature and the social order. Transaction Publishers.

Fadillah, D., \& Jandevi, U. (2020). Mediasocial behavior of Muhammadiyah members in China in the framework of Alexander Wendt's international communication constructivism. Journal of Social Studies (JSS), 16(1), 5164. doi: 10.21831/jss.v16i1.34604.

Fitryarini, I. (2016). Literasi media pada mahasiswa prodi ilmu komunikasi Universitas Mulawarman. Jurnal Komunikasi. 8(1), 51-67. 10.24912/ jk.v8i1.46.

Gumgum, G., Justito, A., \& Nunik, M. (2017). Literasi media: Cerdas menggunakan media sosial dalam menanggulangi berita palsu (hoax) oleh siswa SMA. Pengabdian Kepada Masyarakat, 1(1), 35-40. https://doi.org/1410 - 5675

Haryanto, A. T. (2019). Riset Januari 2019: WhatsApp Digilai Netizen Indonesia. Detiklnet, 1.

Jahja, Y. (2011). Psikologi Perkembangan. Kencana.

Kholis, N. (2017). Melawan budaya informasi hoax. In A. Wahyudin \& M. Sunuantari (Eds.), Melawan Hoax di Media Social dan Media Massa (pp. 108-122). Trust Media Publishing dan ASKOPIS Press.

Mulyana, D. (2008). Metode penelitian kualitatif: Paradigma baru ilmu komunikasi dan ilmu sosial lainnya. In Bandung: Remaja Rosdakarya.

Potter, W. J. (2010). The State of Media Literacy. Journal of Broadcasting and Electronic Media, 54(4), 675-696. https://doi.org/10.1080/o8838151.2011.5 21462

Potter, W. J. (2018). Media literacy. London: Sage Publications.

Prasanti, D., \& Indriani, S. S. (2018). Konvergensi simbolik tentang percakapan remaja laki-laki dalam media sosial group line. Jurnal Komunikasi Universitas Garut: Hasil Pemikiran dan Penelitian, 4(1), 1-8. DOI: http://dx.doi.org/10.10358/jk.v4i1.352

Rianto, P. (2016). Media baru, visi khalayak aktif dan urgensi literasi media. Jurnal Komunikasi Ikatan Sarjana Komunikasi Indonesia, 1(2), 90-96. https://doi. org/10.25008/jkiski.vii2.54

Sarlito, W. S. (2012). Psikologi remaja. Jakarta: PT. Raja Grafindo Persada.

Sary, Y. N. E. (2017). Perkembangan kognitif dan emosi psikologi masa remaja awal. Jurnal Pengabdian Kepada Masyarakat, 1(1), 6-12.

Sugiyono, P. D. (2013). Metode penelitian manajemen. Bandung: Alfabeta, $C V$.

Sukmadinata, N. S. (2009). Metode Penelitian 
Pendekatan. Bandung: Rosdakarya.

Tutiasri, R. P., Kusuma, A., \& Sumardjijati, S. (2019). Perilaku remaja dalam penyebaran hoax di grup WhatsApp. Jurnal Ilmu Komunikasi, 2(1). https:// doi.org/10.33005/jkom.v2i1.36

Wardyaningrum, D. (2013). Komunikasi untuk penyelesaian konflik dalam keluarga: Orientasi percakapan dan orientasi kepatuhan. Jurnal Al-Azhar Indonesia Seri Pranata Sosial, 2(1), 4758. eprints.uai.ac.id/12/1/110-506-1-SM. pdf\%oA\%oA

Widyastuti, Y., Rahmawati, A., \& Purnamaningrum, Y. E. (2009). Kesehatan Reproduksi. Yogyakarta: Fitramaya.

Yuswohady. (2016). Millennial Trends 2016. http://www.yuswohady.com/2016 /01/1 7/millennial-trends-2016/. 